\title{
KEPEKAAN HUMOR DENGAN DEPRESI PADA REMAJA DITINJAU DARI JENIS KELAMIN
}

\author{
Ayu Fitriani \& Nurul Hidayah \\ Fakultas Psikologi \\ Universitas Ahmad Dahlan \\ Jalan Kapas No. 9 Yogyakarta \\ nurul_psi_uad@yahoo.co.id.
}

\begin{abstract}
This study aimed to identify the relationship between sense of humors and depression in adolescents in terms of gender. The subjects of this study were students of SMA Negeri 1 Sewon, Bantul, Yogyakarta class X and $\mathrm{XI}$. The data collection tools of this study used the Beck Depression Inventory (BDI) and the Sense of Humor Scale Version-B, and used the analysis covariance method to analyze the data. The results of this study showed significant differences in depression among female subjects and male subjects with a value of $F=6.905$ and $p=0.010(p<0.05)$ by controlling the sense of humor variable. The average level of female depression (7.284) was higher than male subjects (6.196). This result will be discussed further in this paper.
\end{abstract}

Keywords: Depression, Gender, Sense of Humor

\begin{abstract}
Abstrak
Penelitian ini bertujuan untuk mengetahui hubungan antara kepekaan humor dengan depresi pada remaja ditinjau dari jenis kelamin. Subjek penelitian ini adalah siswa-siswi SMA Negeri 1 Sewon, Bantul, Yogyakarta kelas X dan XI. Pengumpulan data menggunakan Beck Depression Inventory (BDI) dan Skala Kepekaan Humor Versi-B, sedangkan metode analisis data dengan menggunakan Anakova. Hasil penelitian ini menunjukkan dengan mengontrol kepekaan humor, ada perbedaan depresi yang signifikan antara subjek perempuan dan subjek laki-laki dengan nilai $\mathrm{F}=6,905$ dan $\mathrm{p}=0,010(\mathrm{p}<0,05)$. Tingkat depresi subjek perempuan dengan rerata sebesar 7,284 lebih tinggi dibandingkan rerata depresi subjek laki-laki sebesar 6,196.
\end{abstract}

Kata kunci : Depresi, Jenis Kelamin, Kepekaan Humor. 


\section{Pendahuluan}

Lazarus dan Folkman (Santrock, 2003) menjelaskan bahwa kondisi stres dapat terjadi bila terdapat kesenjangan atau ketidakseimbangan antara kemampuan dan tuntutan. Tuntutan merupakan tekanan-tekanan yang tidak dapat diabaikan karena jika tidak dipenuhi, akan menyebabkan konsekuensi yang tidak menyenangkan bagi individu. Tuntutan dapat diartikan sebagai element fisik atau psikososial dari suatu situasi yang harus ditanggapi melalui tindakan fisik atau mental oleh individu, sebagai upaya dalam menyesuaikan diri.

Banyak penelitian menunjukkan jumlah perempuan yang mengalami depresi dua kali lebih banyak dibandingkan laki-laki (Nolen-Hoeksema dalam Davison dkk., 2006). Bahkan sejumlah penelitian menemukan perempuan tiga kali lebih rentan terhadap depresi dibandingkan laki-laki (Kring dkk., 2007). Hal ini berlaku baik pada depresi ringan, sedang, maupun berat. Perbedaan gender ini ditemukan pada sejumlah negara, suku bangsa, dan seluruh tahap usia dewasa. Menariknya, Lubis (2009) menyatakan sebelum remaja, hanya ada sedikit perbedaan tingkat depresi antara anak laki-laki dan perempuan, namun antara usia 11 hingga 13 tahun ada peningkatan kecenderungan depresi pada perempuan. Pada usia 15 tahun perempuan memiliki kecenderungan dua kali lebih besar daripada laki-laki terkena depresi.

Baldwin (2002) menjelaskan bahwa sumber stres pada remaja laki-laki dan perempuan pada umumnya sama, namun dampak beban ini berbeda pada remaja perempuan dan laki-laki. Remaja perempuan lebih peka terhadap lingkungannya. Amir (2005) menambahkan bahwa depresi lebih sering terjadi pada wanita, karena berkaitan dengan ketidakseimbangan hormon pada wanita, misalnya adanya depresi prahaid, postpartum dan postmenopause.

Brizendine (2007) mengatakan bahwa ada perbedaan respon terhadap konflik antara laki-laki dan perempuan. Otak perempuan memiliki kewaspadaan yang negatif terhadap konflik dan stres, pada perempuan konflik memicu hormon negatif sehingga memunculkan stres, gelisah dan rasa takut. Laki-laki sering kali menikmati konflik dan persaingan, bahkan mereka menganggap bahwa konflik memberikan dorongan yang positif. Dapat disimpulkan ketika perempuan menghadapi konflik sering lebih sensitif terhadap respon psikologis sedangkan laki-laki lebih peka terhadap respon fisiologis, sehingga ketika perempuan mendapat tekanan, pada umumnya lebih mudah mereka mengalami stres yang kemudian dapat berlanjut menjadi depresi.

Depresi diibaratkan seperti penyakit flu, sebab depresi dapat terjadi di semua kalangan, tidak terkecuali remaja. Neiger (Dariyo, 2004) menyatakan bahwa usia muda yaitu 15-24 tahun sangat rentan untuk mengalami gangguan depresi. Survei yang dilakukan oleh Avenoli dan Steinberg (Steinberg, 2002) kira-kira 25\% remaja 
merasakan munculnya depresi dan 3\% masuk kategori depresi klinis. Petersen $\mathrm{dkk}$ (Santrock, 2003) mengadakan penelitian pada sampel nonklinis, ditemukan 7\% remaja mengalami depresi klinis, sedangkan penelitian dengan sampel klinis ditemukan 45\% remaja yang mengalami depresi klinis.

Depresi adalah keadaan patah hati atau putus asa yang disertai dengan melemahnya kepekaan terhadap stimuli tertentu, pengurangan aktivitas fisik maupun mental dan kesukaran dalam berpikir (Kartono dan Gulo, 2003). American Psychological Association (APA) (2000) memberikan definisi depresi merupakan perasaan sedih atau kosong yang disertai dengan penurunan minat terhadap aktivitas yang menyenangkan, gangguan tidur dan pola makan, penurunan kemampuan berkonsentrasi, perasaan bersalah yang berlebihan, dan munculnya pikiran tentang kematian atau bunuh diri.

Depresi pada remaja mempengaruhi prestasi sekolah, mereka mengalami kesulitan untuk berkonsentrasi, selain itu depresi juga mempengaruhi fungsi sosial dan kesulitan dalam penyesuaian diri (Nevid dkk., 2005; Lubis, 2009). Weissman (Nevid dkk., 2005) menyatakan depresi pada remaja menyebabkan resiko terjadinya depresi berat, bahkan percobaan bunuh diri di masa dewasa. Maris dkk (Davison dkk., 2006) memperkirakan sebanyak $15 \%$ orang-orang yang didiagnosis menderita depresi berat akhirnya bunuh diri. Melihat keadaan ini, depresi menjadi salah satu masalah kesehatan mental yang menjadi masalah yang perlu mendapat perhatian serius. Prediksi badan kesehatan dunia (WHO) pada tahun 2020 nanti, di negaranegara berkembang, depresi akan menjadi salah satu penyakit mental yang banyak dialami dan depresi berat akan menjadi penyebab kedua terbesar kematian setelah serangan jantung (Lubis, 2009).

Individu yang mengalami depresi dapat dilihat dari gejala yang muncul. Adapun gejala-gejala depresi berdasarkan DSM IV-TR (APA, 2000) sebagai berikut:

(a). Perubahan pada mood,

(b). Perubahan dalam motivasi,

(c). Perubahan pada kognitif,

(d). Perubahan pada fisik dan psikomotorik

Remaja mengalami perubahan dari segi psikomotorik, bergerak lebih lamban dari biasanya, perubahan dalam kebiasaan tidur misalnya terjadi insomnia atau hipersomnia, adanya perubahan dalam berat badan mungkin terjadi penurunan atau penambahan berat badan, terjadi perubahan selera makan (peningkatan atau penurunan selera makan).

Beck (1985) juga memberikan penjelasan tentang simtom-simtom yang 
ditunjukkan seseorang yang mengalami depresi sebagai berikut:
(a). Simtom-simtom emosional,
(b). Simtom-simtom kognitif,
(c). Simtom-simtom motivasional,
(d). Simtom-simtom fisik,

Gambaran kasus depresi, peneliti temukan pada beberapa siswa di SMA Negeri I Sewon, Bantul Yogyakarta. Wawancara telah dilakukan dengan guru bimbingan konseling (BK) dan dua siswa disertai dengan observasi pukul 07.00-10.00 WIB di sekolah tersebut. Hasil wawancara dengan guru BK menunjukkan ada siswa yang merasa malas untuk mengikuti pelajaran ataupun kegiatan di sekolah, hal ini disebabkan siswa tersebut sulit untuk berkonsentrasi di dalam kelas, merasa tidak mampu, ia merasa tidak memiliki kemampuan untuk memenuhi tuntutan mengikuti kegiatan di sekolah. Selain itu ada beberapa siswa yang menunjukkan perilaku sering melamun, terlihat lemas dan tidak bersemangat, menyendiri di kelas, tidak bergabung dengan teman-teman lainnya, keadaan siswa ini disebabkan karena masalah keluarga, orangtua mereka sedang dalam proses perceraian dan ada pula yang yang sedang dalam keadaan yang tidak harmonis. Kasus lain yang sering terjadi adalah masalah ekonomi, beberapa siswa kurang mampu membayar biaya sekolah sehingga seringkali harus menunggak, keadaan ini juga membuat siswa terbebani dan tertekan sehingga tidak dapat fokus dan berkonsentrasi dengan pelajaran di kelas.

Hasil wawancara dengan dua siswa lain rujukan guru BK di sekolah tersebut, mereka mengakui ketika memiliki masalah timbul perasaan tertekan, perasaan sedih, lebih sensitif, dan sulit untuk berkonsentrasi di kelas. Ditambahkan oleh mereka jika memiliki masalah yang belum selesai, mereka sulit tidur, dan merasa malas makan. Selain itu menurut siswa ini, ada teman mereka yang jarang datang ke sekolah disebabkan karena tidak mendapatkan kasih sayang dari kedua orangtuanya.

Semakin banyak stresor yang datang, semakin meningkat pula tingkat stres pada remaja. Stres akan berkembang menjadi lebih buruk lagi bahkan depresi apabila tidak melakukan penanganan yang tepat. Usaha yang dilakukan individu untuk mengontrol tekanan dikatakan sebagai coping (Omizo dalam Santrock, 2003). Strategi coping dapat berupa coping yang berfokus pada masalah yaitu bertindak secara langsung mengatasi masalah atau mencari informasi yang solusi yang relevan. Strategi coping berikutnya yaitu berupa coping yang berfokus pada emosi yaitu upaya untuk mengurangi berbagai reaksi emosional negatif yaitu dengan cara menciptakan emosi positif dalam diri (Davison dkk., 2006). Ketika seseorang mengalami gangguan perasaan maka perasaan didominasi emosi negatif sehingga 
mengalami kesedihan dan distress. Emosi negatif dapat diatasi dengan mengelola emosi positif yang dimiliki seseorang (Durand dan Barlow, 2006).

Hasanat dan Subandi (1998) mengatakan humor dinilai dapat menimbulkan emosi positif, sebab humor menjadikan seseorang dapat tersenyum ataupun tertawa dan memunculkan ekspresi wajah positif. Dapat disimpulkan emosi positif yang ditimbulkan dari humor merupakan salah satu upaya coping yang berfokus pada emosi. Humor dan kepekaan humor yang tinggi dapat membuat seseorang menjadi lebih rileks, tidak tegang lagi, sehingga pikiran pun dapat lebih berkonsentrasi untuk menyelesaikan masalah.

Allport (Schultz, 2005) mengatakan bahwa salah satu ciri-ciri kepribadian yang sehat yaitu kemampuan untuk mengenal dirinya sendiri secara objektif dan mampu untuk menangkap humor terutama yang berkaitan dengan dirinya sendiri, tetapi humor yang dimaksud bukan humor yang menyangkut seks dan agresi. Peneliti berasumsi bahwa remaja yang memiliki kepekaan humor yang baik, dapat terhindar dari depresi sebab remaja tersebut mampu mengembangkan kepribadiannya menjadi lebih sehat.

Humor berasal dari kata umor yaitu You-moors= cairan-mengalir (Hartanti, 2008). Menurut Driver, humor merupakan sifat dari sesuatu atau suatu situasi yang kompleks yang menimbulkan keinginan untuk tertawa (Hartanti, 2008). Secara sederhana humor didefinisikan sebagai sesuatu yang lucu. Sesuatu yang bersifat humor adalah sesuatu yang dapat membuat tertawa (Eysenck dalam Utomo, 2009).

Marten menjelaskan humor sebagai reaksi emosi ketika sesuatu terjadi tidak sesuai dengan yang diharapkan dan reaksi emosi itu membawa kesenangan atau kebahagiaan (Jones, 2010). Menurut Kleverlaan, dkk (Hartanti dan Soerjantini, 2003), seni humor bertujuan untuk meringankan masyarakat dalam menjalani hidupnya. Tentunya setiap masyarakat tertentu berbeda dalam hal cara pengungkapan humornya sesuai dengan karakter daerahnya masing-masing.

Menurut Nilsen (dalam Hasanat, 2002) fungsi humor dibagi menjadi empat fungsi, yaitu fungsi fisiologik, fungsi psikologik, fungsi pendidikan, dan fungsi sosial. Mindess (Hartanti, 2002) berpendapat bahwa fungsi humor yang paling penting adalah kekuatannya untuk membebaskan diri dari banyak rintangan dan pembatasan dalam kehidupan sehari-hari. Humor dapat melepas individu dari berbagai tuntutan yang dialami dan dapat membebaskannya dari perasaan inferioritas.

Berdasarkan penjelasan di atas dapat disimpulkan jika humor memiliki fungsi di antaranya fungsi secara fisiologik yang tentunya memberikan dampak yang baik untuk kesehatan, selain itu fungsi psikologi yang dapat meningkatkan kesehatan mental 
seseorang. Fungsi lain humor yaitu dalam hal pendidikan dan sosial sehingga memudahkan seseorang untuk berinteraksi dengan lingkungannya.

Seseorang memerlukan kepekaan terhadap humor untuk dapat mengamati, merasakan dan mengungkapkan humor, apabila seseorang tidak cukup peka, maka kejadian seperti apapun itu tidak meninggalkan kesan lucu (Sarwono dalam Utomo, 2009). Menurut Meredith (Hartanti, 2008) kepekaan humor merupakan kemampuan untuk menertawakan semua hal termasuk dirinya sendiri dan tetap mencintai dan menyukainya. Hughes (2008) menjelaskan kepekaan humor merupakan kemampuan setiap orang dalam mempersepsikan, mengekspresikan dan menikmati humor. Kepekaan humor dapat menghasilkan hal-hal yang positif tidak hanya terbatas pada coping masalah, ataupun konsep diri yang positif. Menurut Martin dan Lefcourt (Jones, 2010) kepekaan humor menunjukkan frekuensi seseorang ketika tersenyum, tertawa, dan merespon hal-hal yang berkaitan dengan hiburan dalam berbagai situasi. Humor tidak hanya mencakup kognitif dan apresiasi terhadap stimulus humor tetapi berkaitan juga dengan kemampuan dalam memproduksi stimulus humor.

Eysenck (Ruch, 2007) menyatakan istilah kepekaan humor digunakan untuk tiga hal berikut ini :

a. The conformist sense, yaitu tingkat kesamaan di antara individu satu dengan yang lain dalam apresiasi terhadap materi-materi humor.

b. The quantitative sense, yaitu yang menunjukkan seberapa sering seseorang tertawa dan tersenyum, serta seberapa mudah seseorang merasa gembira.

c. The productive sense, yaitu menekankan seberapa banyak seseorang menceritakan cerita-cerita lucu dan membuat orang lain gembira.

Abel (Hartanti, 2008; Noviati, 2011) menjelaskan bahwa kepekaan humor meliputi lima aspek yaitu:

a. kemampuan memahami humor.

b. kemampuan menikmati dan menghargai humor.

c. kemampuan membuat humor

d. menyukai humor dan orang-orang humoris

e. menggunakan humor untuk meredakan ketegangan dan menggunakan humor untuk mencapai tujuan sosial.

Hasanat dan Subandi (1998) mengukur kepekaan humor dengan membuat skala yang berisi gambar humor berdasarkan teori the conformist sense yaitu tingkat apresiasi terhadap materi-materi humor. Hasanat dan Subandi (1999) selanjutnya melakukan pembakuan terhadap skala ini menjadi Skala Kepekaan Humor. Utomo (2006) kemudian melakukan analisis faktor eksploratori pada Skala Kepekaan Humor ini, yang kemudian menghasilkan empat faktor yaitu kekerasan, kekesalan, parodi, 
dan joke. Hasil analisis faktor eksploratori menunjukkan materi humor yang bersifat kekerasan memiliki bobot yang paling besar dibandingkan indikator yang lainnya. Pemaparan di atas dapat menjelaskan bahwa apresiasi terhadap materi humor dapat menunjukkan kepekaan humor seseorang.

Seseorang yang peka terhadap humor memiliki banyak keuntungan. Kelly (Zulkarnain dan Novliadi, 2009) menyatakan seseorang yang memiliki kepekaan humor yang lebih tinggi, akan lebih ceria, lebih termotivasi, memiliki self esteem yang lebih tinggi.

Keadaan hormonal antara laki-laki dan perempuan merupakan salah satu hal penting dalam penyesuaian diri pada kondisi fisik dan psikis. Brizendine (2007) menyatakan hormon testosteron dan progesteron diduga mampu mempengaruhi peningkatan agresifitas sehingga laki-laki cenderung stabil ketika beraktivitas, sedangkan hormon estrogen diduga mempengaruhi psikis dan perasaan perempuan pada kondisi tertentu. Kondisi-kondisi tertentu ini akan berpengaruh secara psikis terhadap perilaku perempuan dalam menyelesaikan permasalahan yang dihadapi. Hal ini yang mempengaruhi kecenderungan depresi remaja perempuan lebih tinggi daripada remaja laki-laki.

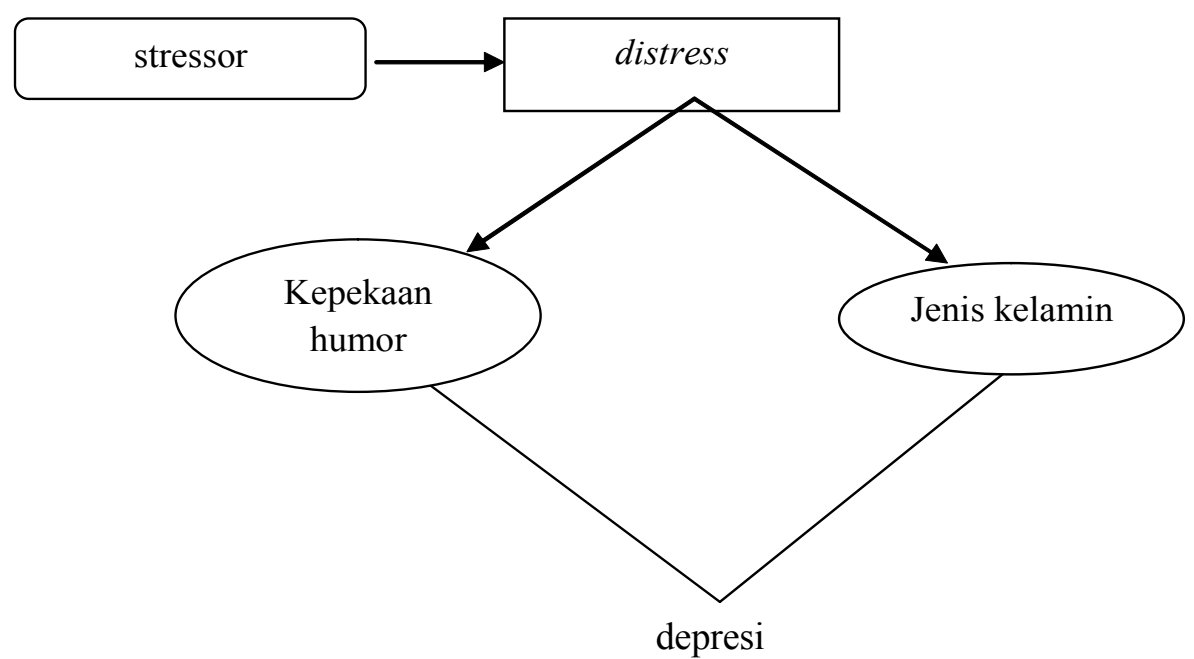

1. Depresi laki-laki $<$ depresi perempuan.

2. $\mathrm{KH}$ tinggi $=$ depresi rendah

Gambar 1. Skema hubungan kepekaan humor dengan depresi pada remaja ditinjau dari jenis kelamin 
Berdasarkan penjabaran permasalahan di atas, dapat diasumsikan bahwa remaja perempuan memiliki tingkat depresi yang tinggi dibandingkan remaja lakilaki, meskipun mengalami stresor yang sama. Selanjutnya kepekaan humor secara bersamaan ternyata berpengaruh terhadap depresi. Melihat hal ini, maka peneliti tertarik untuk meneliti perbedaan depresi antara remaja perempuan dan remaja lakilaki dengan mengendalikan pengaruh kepekaan humor. Hipotesis dalam penelitian ini adalah ada perbedaan depresi antara remaja perempuan dan remaja laki-laki, dengan mengontrol variabel kepekaan humor. Remaja perempuan memiliki tingkat depresi lebih tinggi daripada remaja laki-laki.

\section{Metode Penelitian}

Populasi penelitian ini adalah siswa kelas X-XI SMA Negeri 1 Sewon, Bantul, Yogyakarta. Teknik yang digunakan dalam pengambilan sampel ini adalah metode cluster random sampling yaitu teknik pengambilan sampel dengan cara melakukan randomisasi terhadap kelompok, bukan terhadap individu (Azwar, 2003). Dalam penelitian ini, peneliti akan melakukan randomisasi kelas pada kelas X dan pada kelas XI. Hasil randomisasi akan menghasilkan sebanyak dua kelas X dan dua kelas XI untuk dijadikan sampel dalam penelitian ini.

Metode pengumpulan data dilakukan dengan penyebaran Beck Depression Inventory (BDI) untuk mengukur depresi subjek. Pengukuran terhadap kepekaan humor subjek, peneliti menggunakan Skala Kepekaan Humor yang berisi sejumlah aitem figural berupa gambar kartun.

Metode analisis yang digunakan dalam penelitian ini adalah analisis statistik parametrik. Data dianalisis dengan menggunakan Analisis Ko-varians (Anakova).

\section{Hasil dan Pembahasan}

Tabel 1. Data Statistik Deskriptif

\begin{tabular}{cccccccccc}
\hline \multirow{2}{*}{ Variabel } & \multicolumn{3}{c}{ Skor Empirik } & \multicolumn{4}{c}{ Skor Hipotetik } \\
\cline { 2 - 9 } & Max & Min & Mean & SD & Max & Min & $\boldsymbol{M}$ & $\boldsymbol{\sigma}$ \\
\hline $\begin{array}{c}\text { Kepekaan } \\
\text { Humor }\end{array}$ & 83 & 31 & 60,50 & 11,52 & 125 & 25 & 75 & 16,66 \\
\hline BDI & 16 & 1 & 7,01 & 3,31 & 63 & 0 & 31,5 & 10,5 \\
\hline
\end{tabular}


Analisis deskriptif terhadap data penelitian ini dilakukan dengan tujuan untuk memberi gambaran mengenai kecenderungan respon subjek (berupa mean atau ratarata) terhadap variabel-variabel penelitian yaitu Kepekaan Humor dan BDI (Beck Depression Inventory). Berdasarkan hasil analisis data statistik deskriptif dapat diketahui skor empirik dan skor hipotetik pada masing-masing variabel.

Berdasarkan data statistik deskriptif di atas, maka dapat dilakukan suatu pengkategorisasian skor pada variabel penelitian. Kategorisasi pada variabel kepekaan humor dengan menetapkan kriteria kategori yang didasari oleh suatu asumsi bahwa skor subjek dan populasi terdistribusi secara normal sehingga dapat dibuat skor teoritis terdistribusi menurut model normal, untuk mengetahui tinggi rendahnya skor yang diperoleh subjek dapat dilakukan pengkategorisasian dengan menetapkan suatu kriteria. Skor yang diperoleh subjek diklasifikasikan menggunakan tiga kategori yaitu rendah, sedang dan tinggi untuk Skala Kepekaan Humor,sedangkan kategorisasi depresi dengan menggunakan norma penggolongan depresi BDI.

Berdasarkan kategorisasi masing-masing aspek ternyata mayoritas subjek memiliki kepekaan humor pada kategori sedang, sehingga dapat diambil kesimpulan bahwa kepekaan humor mayoritas subjek penelitian termasuk kategori sedang. Berdasarkan kategorisasi dapat diambil kesimpulan bahwa tingkat depresi subjek penelitian termasuk kategori normal.

Uji anakova dengan test of between-Subjects Effects bertujuan untuk mengetahui perbedaan depresi antara remaja perempuan dan remaja laki-laki dengan mengontrol variabel kepekaan humor. Berdasarkan hasil analisis test of betweenSubjects Effects tanpa interaksi antara jenis kelamin dan kepekaan humor menunjukkan bahwa variabel jenis kelamin berpengaruh signifikan terhadap depresi siswa dengan nilai F sebesar 6,905 dan probabilitas $0,010(p<0,05)$. Begitu juga dengan variabel covariate kepekaan humor berpengaruh sangat signifikan terhadap depresi siswa dengan nilai F sebesar 8,860 dan probabilitas $0,004(\mathrm{p}<0,01)$. Dapat disimpulkan ada perbedaan yang signifikan depresi antara remaja perempuan dan remaja laki-laki, dengan rerata depresi remaja perempuan sebesar 7,284 lebih tinggi daripada rerata depresi remaja laki-laki yaitu sebesar 6,196.

Hasil penelitian menunjukkan bahwa dengan mengendalikan variabel kepekaan humor, ada perbedaan depresi yang signifikan antara subjek perempuan dan subjek laki-laki, yang ditunjukkan dengan nilai $F$ sebesar 6,905 dan probabilitas 0,010 $(p<0,05)$. Tingkat depresi subjek perempuan dengan rerata depresi sebesar 7,284 lebih tinggi dibandingkan tingkat depresi subjek laki-laki dengan rerata depresi sebesar 6,196. Perbedaan depresi antara subjek perempuan dan subjek laki-laki disebabkan 
salah satunya adanya perbedaan keadaan hormonal dan keadaan fisologis. Hal ini yang mempengaruhi mereka dalam mengatasi stressor yang mereka hadapi.

Seligman dan Rosehan (1989) menjelaskan beberapa alasan adanya perbedaan terjadinya depresi antara laki-laki dan perempuan yaitu yang pertama perempuan lebih ekspresif untuk menceritakan simtom depresi yang dialami dibandingkan lakilaki. Alasan yang kedua yaitu secara biologis aktivitas enzim kimia, faktor biologi, dan tiap bulannya terjadi depresi pramenstruasi yang mempengaruhi kondisi emosi perempuan. Alasan yang ketiga berkaitan dengan keputusasaan yang menyebabkan depresi, perempuan lebih mudah merasa putus asa dibanding laki-laki, sehingga depresi lebih sering terjadi pada perempuan. Alasan yang terakhir, wanita lebih berpikir rigid dibanding laki-laki, sehingga perempuan lebih mudah khawatir dan menjelaskan hal-hal buruk yang terjadi dalam kehidupannya, sedangkan laki-laki lebih banyak melakukan aksi dan jarang memikirkan hal-hal yang bersifat rigid.

Pemaparan di atas sejalan dengan pendapat yang dikemukakan oleh Gunadi (Zulkarnain dan Novliadi, 2009) yang menyatakan bahwa perempuan lebih peka dengan emosinya, yang pada akhirnya peka juga terhadap perasaan-perasaan cemas sehingga menimbulkan perasaan tertekan. Perbedaan itu bukan hanya dipengaruhi faktor emosi tetapi juga dipengaruhi oleh faktor kognitifnya. Perempuan cenderung melihat hidup atau peristiwa yang dialaminya dari segi detail, sedangkan cara berpikir laki-laki lebih umum atau global. Individu yang melihat lebih detil terhadap masalah, akan lebih mudah dirundung kecemasan karena informasi yang dimiliki lebih banyak dan akhirnya dapat menekan perasaan individu tersebut.

Berdasarkan penjabaran di atas, maka dapat disimpulkan bahwa hipotesis diterima. Dari hasil penelitian ini tampak bahwa variabel kepekaan humor (kovariabel) ternyata memberikan pengaruh yang sangat signifikan terhadap variabel depresi yang ditunjukkan dengan nilai F sebesar 8,860 dan probabilitas $0,004(\mathrm{p}<0,01)$, melihat pengaruh ini maka dalam penelitian ini variabel kepekaan humor perlu dikontrol, agar dapat terlihat perbedaan depresi antara subjek laki-laki dan perempuan tanpa ada pengaruh kepekaan humor terhadap depresi tersebut.

Kepekaan humor memiliki pengaruh yang sangat signifikan terhadap depresi karena berkaitan sebagai salah satu strategi coping. Seseorang yang memiliki masalah akan berusaha menemukan strategi coping. Ketika individu tidak dapat melakukan coping yang efektif, maka akan muncul distres yang dapat berlanjut menjadi depresi. Strategi coping dapat berupa coping yang berfokus pada masalah yaitu bertindak secara langsung mengatasi masalah atau mencari informasi solusi yang relevan. Strategi coping berikutnya berupa coping yang berfokus pada emosi yaitu upaya untuk 
mengurangi berbagai reaksi emosional negatif yaitu dengan cara menciptakan emosi positif dalam diri. Emosi positif akan mengurangi bahkan menghilangkan beberapa simtom yang tidak menyenangkan dari emosi negatif(Davison dkk., 2006).

Hasil penelitian ini sejalan dengan penelitian Danzer, Dale dan Herbert (Hartanti, 2002) yang menunjukkan bahwa peningkatan suasana hati dan tersenyum dapat menurunkan tingkat depresi seseorang. Penelitian ini juga didukung dengan penelitian Thorson dan Powell (Zulkarnain dan Novliadi, 2009), yang menunjukkan bahwa sense of humor berkorelasi negatif dengan neurotisme, pesimisme, self-esteem rendah, depresi, dan mood yang buruk.

Berdasarkan kategori skor depresi, mayoritas subjek penelitian (79\%) berada pada kategori normal. Kategori normal ini berarti subjek mengalami perubahan mood atau perasaan yang wajar. Keadaan ini menjelaskan bahwa subjek memiliki tempat untuk menceritakan masalah dan memudahkan mereka untuk menentukan coping masalah yang efektif, sehingga membuat mereka terhindar dari depresi yang merugikan dirimereka sendiri. Hal ini dikarenakan SMA Negeri 1 Sewon menyediakan kelompok konseling teman sebaya, untuk memudahkan siswa untuk bercerita ataupun berkonsultasi dengan teman sebaya mereka ketika memiliki masalah daripada harus berkonsultasi langsung pada guru BK.

Berdasarkan kategorisasi skor kepekaan humor, mayoritas subjek (89\%) memiliki kepekaan humor pada kategori sedang. Kategori sedang ini berarti bahwa mayoritas subjek cukup peka dalam mengamati materi humor, sehingga kejadian yang berbau humor dapat meninggalkan kesan lucu bagi subjek. Subjek penelitian ini rata-rata berusia 15-17 tahun, yang berarti mereka memasuki fase remaja tengah. Dalam fase ini setidaknya subjek telah belajar dan memiliki pengalaman dalam menyelesaikan masalah. Semakin bertambahnya usia dan tingkat pendidikan maka seseorang memiliki kemampuan dalam memilih strategi coping pun untuk menyelesaikan masalah dengan lebih efektif(Hasanat, 1994).

\section{Simpulan}

Berdasarkan hasil analisis data, pengujian hipotesis dan pembahasan hasil penelitian, dapat diambil kesimpulan dengan mengendalikan kepekaan humor, ada perbedaan yang signifikan antara depresi remaja perempuan dan remaja laki-laki. Tingkat depresi remaja perempuan lebih tinggi dibandingkan tingkat depresi remaja laki-laki. Tingkat depresi subjek mayoritas berada pada kategori normal. Tingkat kepekaan humor subjek mayoritas berada pada kategori sedang. 


\section{Daftar Pustaka}

American Psychological Association (APA). (2000). Diagnostic and Statistical Manual of Mental Disorders (DSMIV-TR) Fourth Edition. Washington DC:APA.

Amir, N. (2005). Depresi Aspek Neurologi Diagnosisi dan Tatalaksana . Jakarta: Fakultas Kedokteran Universitas Indonesia.

Azwar, S. (2003). Metodologi Penelitian. Yogyakarta: Pustaka Pelajar

Baldwin, R. D. (2002). Stress and Illness in Adolescence: Issue of Race ang Gender. http:www.Fidarticles.com. Diakses 6Agustus 2011.

Brizendine, L. (2007). The Female Brain. Penerjemah: Meda Satrio. Jakarta: Ufuk Press.

Beck, A. T, (1985). Depression. Philadelphia: First University of Fesilvania.

Dariyo, A. (2004). Psikologi Perkembangan Remaja. Bogor Selatan: Ghalia Indonesia.

Davison, G. C., Neale, J.M, \& Kring, A.M. (2006). Psikologi Abnormal Edisi Ke-9. Penerjemah: Noermalasari Fajar. Jakarta: PT.Grafindo Persada.

Diakses pada tanggal 18 Maret 2011.

Durand, V. M. \& Barlow, D. H. (2006). Intisari Psikologi Abnormal Edisi Ke-4. Penerjemah: Yogyakarta: Pustaka Pelajar.

Fausiah, F., \& Widury, J. (2006). Psikologi Abnormal Klinis Dewasa. Jakarta: Universitas Indonesia.

Hampes, W. P., College, B. H., \& Illinois, M. (2010). The Relation between Humor Style and Empathy. Europe's Journal Psychology. Vol. 3: 34-45.

Hartanti. (2002). Peran Sense of Humor dan dukungan sosial pada tingkat depresi Penderita Dewasa Pascastroke. Anima, Indonesian Psychological Journal. 17, 2: 107-119.

Hartanti. (2008). Apakah Selera Humor Menurunkan Stres? Sebuah Meta-analisis. Anima, Indonesian Psychological Journal. Vol. 24, No. 1: 38-55.

Hartanti, R., \& Soerjantini. (2003). Peran Sense of Humor Pada Dampak Negatif Stres Kerja. Anima, Indonesian Psychological Journal. 18, 4: 393408. 
Hasanat, N. U. (1994). Apakah Wanita Lebih Depresif Daripada Pria? Laporan penelitian (tidak diterbitkan). Yogyakarta: Fakultas Psikologi Universitas Gadjah Mada.

Hasanat, N. U., \& Subandi. (1998). Pengembangan Alat Kepekaan Terhadap Humor. Jurnal Psikologi. 1: 17-25.

Hasanat, N. U., \& Subandi. (1999). Pembakuan Alat Kepekaan Terhadap Humor. Laporan Penelitian. (tidak diterbitkan). Yogyakarta: Fakultas Psikologi Universitas Gadjah Mada.

Hodgkinson, L. (1991). Smile Therapy. London: MacDonald \& Co. (Publishers) Ltd.

Hughes, L., W. (2008). A Correlational Study of the Relationship between Sense of Humor and Positive Psychological Capacities. Economics and Business Journal: Inquiries and Perspectives. Vol. 1, No. 1: 46-55.

Jones, C. L. (2010). The Relationship between Health Status, Life Satisfaction, and Humor as a Coping Mechanism Among Noninstitutionalized. Tesis. The Florida State University College OfEducation

Kartono, K., \& Gulo, D. (2003). Kamus Psikologi. Bandung: Pionir Jaya.

Kring, A. M., Davison, G. C., Neale, J. M., \& Johnson, S. L. (2007). Abnormal Psychology 10th Edition. United States of America: John Wiley and Sons, Inc.

Lubis, L. N. (2009). Depresi Tinjauan Psikologis. Jakarta: Kencana.

Martin, R. A. (2007). The Psychology of Humor: an Integrative Approach. California: Elsevier Academic Press.

Nevid, J. S., Rathus, S. A., \& Greene, B. (2005). Psikologi Abnormal Edisi kelima Jilid 2. Penerjemah: Tim Fakultas Psikologi UI. Jakarta: Erlangga.

Noviati, N. P. (2011). Selera Humor, Dampak Secara Psikologi dan Aplikasinya di Tempat Kerja. Proceeding Seminar Nasional Psikologi 2011. Yogyakarta: Fakultas Psikologi Universitas Ahmad Dahlan.

Ruch, W. (2007). The Sense of Humor: Explorations of a Personality Characteristic. Berlin: Walter de Gruyter.

Santrock, J. W. (2003). Adolescence Perkembangan Remaja. Penerjemah: Shinto B. Adelar dan Sherly Saragih. Jakarta: Erlangga. 
Schultz, D. (2005). Psikologi Pertumbuhan Model-model Kepribadian Sehat. Yogyakarta: Kanisius.

Seligman, M. E. P., \& Rosehan, D. L. (1989). Abnormal Psychology Second Edition. New York: WW. Norton.

Steinberg, L. (2002). Adolescence Sixth Edition. New York: Mc Graw Hill.

Utomo, U. H. N. (2006). Validitas dan Reliabiltas Skala Kepekaan Humor. Tesis. (tidak diterbitkan). Yogyakarta: Universitas Gadjah Mada

Utomo, U. H. N. (2009). Sense of Humor: Studi Psikometris tentang Skala Kepekaan terhadap Humor versi A dan B. Laporan Penelitian. (tidak diterbitkan). Yogyakarta: Universitas Ahmad Dahlan.

Zulkarnain \& Novliadi, F. (2009). Sense of Humor dan Kecemasan Menghadapi Ujian di Kalangan Mahasiswa. Majalah Kedokteran Nusantara. Vol. 42, No. 1: 48-54. 